\title{
Anti-tumor effects of anti-PD-L1 therapy in an orthotopic bladder tumor model
}

\author{
Amanda Lyon ${ }^{1}$, Jonathan Fallon', Benjamin Boyerinas ${ }^{1}$, Robert Schmitz', Kenneth W Hance ${ }^{2}$, Yan Lan², \\ Helen Sabzevari ${ }^{2}$, Kwong Tsang ${ }^{3}$, Jeffrey Schlom³ ${ }^{3}$ John Greiner ${ }^{1 *}$ \\ From Society for Immunotherapy of Cancer 29th Annual Meeting \\ National Harbor, MD, USA. 6-9 November 2014
}

Antibodies that block PD-1/PD-L1 interactions have shown efficacy against both lung and skin cancers in early-stage clinical trials, and may also be effective in other tumor types, particularly bladder tumors. PD-L1 expression has been previously reported to correlate with high-grade tumors, a high recurrence rate, and reduced survival rate in patients with bladder cancer. These findings and the high frequency of somatic mutations found in bladder tumors indicate that bladder cancer patients may respond well to anti-PD-L1 therapy. Both murine (MB49, MBT-2) and human (J82, T24, TCCSUP) bladder cancer cell lines constitutively express PD-L1 as determined by flow cytometry. As expected, in vitro IFN- $\gamma$ addition up-regulated PD-L1 expression levels on each of those tumor cells. A human $\operatorname{IgG}_{1}$ antiPD-L1 antibody, MSB0010718C, induced ADCC activity in vitro against all three human bladder cancer cell lines following treatment with IFN- $\gamma$. In initial in vivo murine studies, the growth of s.c. MB49 tumors in syngeneic mice was significantly delayed following three i.p. injections of $400 \mu \mathrm{g}$ of the MSB0010718C anti-PD-L1 antibody. An orthotopic bladder model consisting of the MB49 cells tagged with luciferase (MB49-luc) was also used to evaluate the antitumor efficacy of the anti-PDL1 antibody. MB49-luc cells were instilled intravesically (bladder) in B6 mice. Beginning at 7 or 10 days postinstillation, three i.p. injections of the anti-PD-L1 antibody substantially reduced tumor volumes, as determined by intravital imaging, leading to long-term tumor-free survival for $40-60 \%$ of the treated mice. While initial immune cell subset depletion studies implicated both CD4+ and CD8+ T cells, continuing efforts will further define the cellular mechanisms responsible for the antitumor effects of

${ }^{1} \mathrm{CCR}$, National Cancer Institute, $\mathrm{NIH}$, Bethesda, MD, USA

Full list of author information is available at the end of the article the anti-PD-L1 antibody. Taken together, these results suggest that MSB0010718C therapy might be used to activate both innate and adaptive immune mechanisms to treat PD-L1-expressing bladder tumors. Furthermore, the MB49 tumor model can be used to evaluate the combined effects of anti-PD-L1 and other therapeutic agents, particularly ones that induce IFN- $\gamma$ production and tumor PD-L1 up-regulation. MSB0010718C is currently being evaluated in a Phase I clinical trial (NCT01772004).

\section{Authors' details}

${ }^{1} \mathrm{CCR}$, National Cancer Institute, NIH, Bethesda, MD, USA. ${ }^{2}$ EMD Serono Research \& Development Institute, Inc., Billerica, MA, USA. ${ }^{3}$ Laboratory of Tumor Immunology and Biology, CCR, NCl, NIH, Bethesda, MD, USA.

Published: 6 November 2014

doi:10.1186/2051-1426-2-S3-P101

Cite this article as: Lyon et al: Anti-tumor effects of anti-PD-L1 therapy in an orthotopic bladder tumor model. Journal for ImmunoTherapy of Cancer 2014 2(Suppl 3):P101.

Submit your next manuscript to BioMed Central and take full advantage of:

- Convenient online submission

- Thorough peer review

- No space constraints or color figure charges

- Immediate publication on acceptance

- Inclusion in PubMed, CAS, Scopus and Google Scholar

- Research which is freely available for redistribution 